J. Clin. Chem. Clin. Biochem.

Vol. 20, 1982, pp. 185-189

\title{
Kinetic Enzymatic Determination of Creatinine by a Rapid Semiautomated Procedure
}

\author{
By P. Bonvicini, G. Ceriotti and Teresa de'Besi \\ Laboratorio Centrale di Analisi, Ospedale Civile, Padova, Italy
}

(Received June 12/October 5, 1981)

Summary: The enzymatic method of creatinine determination, based on the transformation of creatinine to creatine by creatinine amido-hydrolase (EC 3.5.2.10) and subsequent evaluation of the creatine, has been automated as a kinetic initial rate procedure. This was achieved by using a preincubation period under conditions that reduce the interference by accessory reactions to a very low and constant value, followed by a relatively high concentration of creatinine amido-hydrolase as a starter.

\section{Kinetische enzymatische Bestimmung von Kreatinin mit einem schnellen halbmechanisierten Verfahren}

Zusammenfassung: Kreatinin wird mit Kreatinin-Amidohydrolase (EC 3.5.2.10) in Kreatin übergeführt und dieses in einem mechanisierten Verfahren durch Messung der Anfangsgeschwindigkeit eines gekoppelten Optischen Tests bestimmt. Dieses Verfahren wird ermöglicht durch Vorinkubation unter Bedingungen, die die Interferenz durch Nebenreaktionen niedrig und konstant halten, sowie eine relativ hohe Konzentration an Kreatinin-Amidohydrolase als Startreagenz.

\section{Introduction}

Even small variations in the normal upper range of plasma creatinine concentration may be of outmost clinical importance for monitoring renal function, especially in certain situations at risk, e.g., in renal transplanted patients (1).

The Jaffé reaction as routinely performed ị not specific enough to ensure adequate accuracy, owing to the unpredictable presence of interfering "pseudocreatinines".

Specific enzymatic determinations (2-5) should overcome this difficulty. The method based on transformation of creatinine to creatine by the action of creatinine amido-hydrolase (2) (EC 3.5.2.10) and the subsequent enzymatic evaluation of the latter, has recently become available. In its present form it is however rather impractical for routine purposes. In fact it requires a rather large volume of serum and a long incubation time; furthermore the absorbances of the sample and of the serum blank (without creatinine amido-hydrolase) must be measured immediately one after the other, because of accessory reactions that proceed in parallel in both of them, even after the incubation period. Automation of the endpoint reaction is therefore impossible under the conditions proposed.

To overcome these difficulties Moss et al. (3) have worked out a kinetic method, which however still requires $10 \mathrm{~min}$ for each determination and the use of rather large amounts of the costly creatinine amido-hydrolase.
In the present research we have studied the conditions for a rapid kinetic determination which utilizes reduced volumes of serum and reagents, and is suitable for semiautomated procedures.

\section{Materials and Methods}

\section{Reaggents}

The Test-Combination Creatinine Enzymatic kit (from Boehringer Mannheim) wàs used. Standard solutions in deionized water were prepared with reagent grade creatinine (C. Erba, Milano Italy) at concentrations ranging from 88 to $884 \mu \mathrm{mol} / 1$.

\section{Preparation of the solutions}

Reagent 1: The reagent is prepared by adding to $50 \mathrm{ml}$ of buffer (glycine $100 \mathrm{mmol} / 1$, potassium phosphate $75 \mathrm{mmol} / \mathrm{l}$, $\mathrm{pH} 8.0$ ) $1.0 \mathrm{ml}$ of the coenzyme/substrate solution (NADH $12 \mathrm{mmol} / \mathrm{l}$, ATP $66 \mathrm{mmol} / \mathrm{l}$, phosphoenolpyruvate $22 \mathrm{mmol} / \mathrm{l}$ ) and $1.0 \mathrm{ml}$ of the solution containing accessory enzymes (creatine kinase $\geqslant 500 \mathrm{kU} / 1$; pyruvate kinase $\geqslant 200 \mathrm{kU} / 1$, lactate dehydrogenase $\geqslant 500 \mathrm{kU} / 1$; magnesium chloride $100 \mathrm{mmol} / \mathrm{l}$ ).

Reagent 2: The creatinine amido-hydrolase solution of the kit, diluted fifteen-fold with the buffer up to a concentration of $33 \mathrm{kU} / 1$, is used as starter.

Procedure

A Reaction Rate Analyzer LKB 8600 (Brфmma-Sweden) was used, positioned as follows: background 0.7 ; decrease; delay; range 0.05 ; time $1 \mathrm{~min} ; \lambda 340 \mathrm{~nm}$ ). The procedure is shown in table 1.

During the first $20 \mathrm{~s}$ the reaction is disturbed by the formation of small bubbles, but thereafter a quasi straight line response is obtained. The calculation is therefore based on the $\Delta A$ between 30 and $60: \mathrm{s}$ after addition of the starter. The results are calculated from a standard curve. 
Tab. 1. Procedure of the proposed method on LKB 8600 .

\begin{tabular}{|c|c|c|c|c|}
\hline \multicolumn{2}{|c|}{ Pipette into the cuvette: } & \multirow{2}{*}{$\begin{array}{l}\begin{array}{l}\text { Sample or } \\
\text { standard }\end{array} \\
600\end{array}$} & \multirow{2}{*}{$\begin{array}{l}\begin{array}{l}\text { Sample } \\
\text { blank }\end{array} \\
600\end{array}$} & \multirow{2}{*}{$\begin{array}{l}\begin{array}{l}\text { Rea- } \\
\text { gent } \\
\text { blank }\end{array} \\
600\end{array}$} \\
\hline Reagent 1 & $(\mu 1)$ & & & \\
\hline $\begin{array}{l}\text { Sample* } \\
\text { or standard }\end{array}$ & $(\mu l)$ & 100 & 100 & - \\
\hline Water & $(\mu l)$ & - & - & 100 \\
\hline \multicolumn{5}{|c|}{ Incubate $15 \mathrm{~min}$ at $37^{\circ} \mathrm{C}$} \\
\hline $\begin{array}{l}\text { Reagent } 2 \\
\text { (starter) }\end{array}$ & $(\mu l)$ & 75 & - & 75 \\
\hline Water & $(\mu \mathrm{l})$ & - & 75 & - \\
\hline
\end{tabular}

* For urine dilute 1 to 25 with water.

\section{Other methods}

The proposed enzymatic procedure was compared with three methods based on the Jaffé alkaline picrate reaction namely:

1) a direct kinetic method on a centrifugal analyzer (6) (CentrifiChem, Union Carbide),

2) a standard continuous-flow method, with deproteinization by dialysis, performed on SMAC ${ }^{\mathrm{TM}}$ (Technicon Instrument Corp., Tarrytown, N.Y.) and

3) the Slot's method (7) which involves sulfotungstate deproteinization and evaluation of the creatinine concentration from the difference of absorbances measured at alkaline and acid $\mathrm{pH}$.

A comparison was also made with the original end point enzymatic procedure of the Boehringer kit.

\section{Results}

\section{Serum blanks}

The interference of non specific NADH consuming reactions is apparently the most difficult point in the methods proposed up to now because they induce a decrease of absorbance in the serum blanks in the absence of creatinine amido-hydrolase. In the methods proposed here, the decrease of absorbance registered after the preincubation period in 100 random serum blanks, adding water instead of the starter amido-hydrolase, was very small and constant and comparable to that of the reagent blank without serum (tab. 2). Therefore it has been assumed that the value found could be considered as a constant to be subtracted from the $\Delta \mathrm{A} / \mathrm{min}$ of each sample. The inaccuracy thus introduced can be cal-

Tab. 2. Decrease in absorbance at $340 \mathrm{~nm}$.

\begin{tabular}{lc}
\hline Sample & $\begin{array}{l}\Delta \mathrm{A} / \mathrm{min} \times 10^{3} \\
(\mathrm{mean} \pm \mathrm{SD})\end{array}$ \\
\hline $\begin{array}{l}\text { Serum blank } \\
(100 \text { random serum samples) }\end{array}$ & $2.45 \pm 0.65$ \\
$\begin{array}{l}\text { Reagent blank } \\
(\mathrm{n}=30)\end{array}$ & $1.50 \pm 0.12$ \\
$\begin{array}{l}\text { Creatinine standard }(265 \mu \mathrm{mol} / \mathrm{l}) \\
(\mathrm{n}=30)\end{array}$ & $30.70 \pm 0.72$ \\
\hline
\end{tabular}

culated from SD of serum blanks and apparently does not produce a serious bias $( \pm 1 \mathrm{SD}= \pm 5.3 \mu \mathrm{mol} / \mathrm{l})$.

\section{Precision}

Within-day and day-to-day precision were determined by 30 and 20 determinations respectively on two serum pools (tab. 3). For the day-to-day precision the samples were stored in $0.5 \mathrm{ml}$ aliquots at $-20^{\circ} \mathrm{C}$ and thawed when required.

Tab. 3. Precision of the method.

\begin{tabular}{|c|c|c|c|c|c|}
\hline & & \multicolumn{2}{|c|}{ Within day } & \multicolumn{2}{|c|}{ Day to day } \\
\hline $\mathrm{n}$ & (pooled sera) & \multicolumn{2}{|c|}{30} & \multicolumn{2}{|c|}{20} \\
\hline $\begin{array}{l}\overrightarrow{\mathrm{x}} \\
\text { SD } \\
\mathrm{CV}\end{array}$ & $\begin{array}{l}(\mu \mathrm{mol} / 1) \\
(\mu \mathrm{mol} / 1) \\
(\%)\end{array}$ & $\begin{array}{r}97 \\
2.9 \\
3.0\end{array}$ & $\begin{array}{r}548 \\
8.2 \\
1.5\end{array}$ & $\begin{array}{l}98 \\
4.9 \\
4.4\end{array}$ & $\begin{array}{r}560 \\
10.5 \\
1.9\end{array}$ \\
\hline
\end{tabular}

\section{Linearity}

The response is directly proportional to the creatinine concentration up to $884 \mu \mathrm{mol} / \mathrm{l}$ (fig. 1).

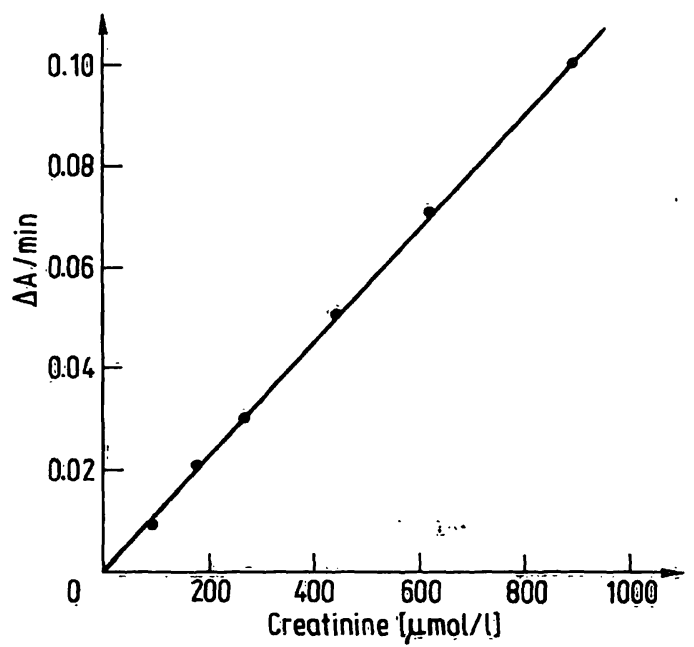

Fig. 1. Standard curve for the proposed kinetic enżymatic method.

\section{Recovery}

The average recovery of known amounts of standard creatinine solutions added to a serum poôl was $98.98 \%$ (tab. 4).

Tab. 4. Recovery test.

\begin{tabular}{llc}
\hline $\begin{array}{l}\text { Creatinine added } \\
(\mu \mathrm{mol} / \mathrm{l})\end{array}$ & $\begin{array}{l}\text { Creatinine found* } \\
(\mu \mathrm{mol} / 1)\end{array}$ & $\begin{array}{l}\text { Recovery } \\
(\%)\end{array}$ \\
\hline 0 & 132.6 & - \\
88 & 227.8 & 101.3 \\
265 & 389.0 & 93.3 \\
442 & 583.4 & 106.6 \\
619 & 744.3 & 94.6 \\
& & $\overline{\mathrm{x}} \fallingdotseq 98.98$ \\
\hline
\end{tabular}

* mean of triplicate assays 


\section{Comparison with other methods}

Parallel determinations of creatinine were performed by the methods indicated above and the present method on 87 serum samples with creatinine concentrations ranging from 17 to $1091 \mu \mathrm{mol} / 1$. Superimposable results were obtained when the endpoint enzymatic method, performed according to the Boehringer kit, was compared with the proposed kinetic enzymatic procedure (fig. 2 and tab. 5).

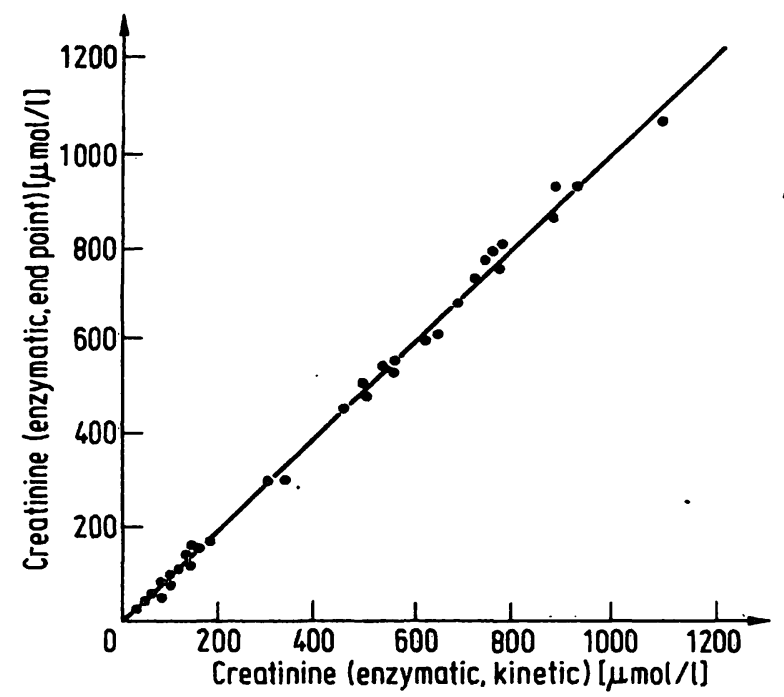

Fig. 2. Comparison of the proposed kinetic enzymatic method with that of the original Boehringer-Mannheim kit.

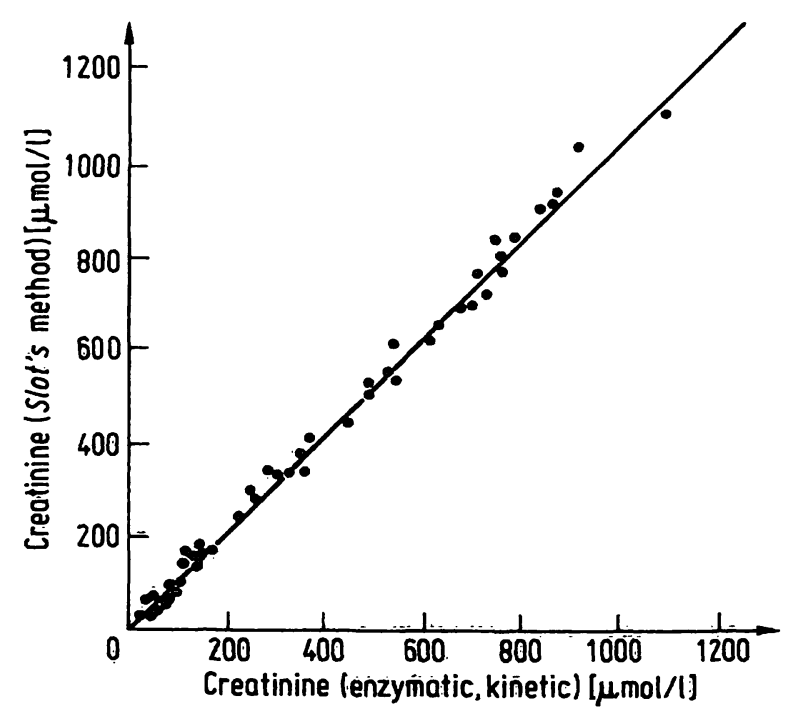

Fig. 3. Comparison of the proposed kinetic enzymatic method with the two pHs colorimetric method, according to Slot.

$y=5.42 \mu \mathrm{mol} / 1+1.035 x ; r=0.9980 ; n=87$.
As analysis of the data obtained by the same method and the picrate methods, by the Student's t-test for paired values, showed significant differences (tab. 5).

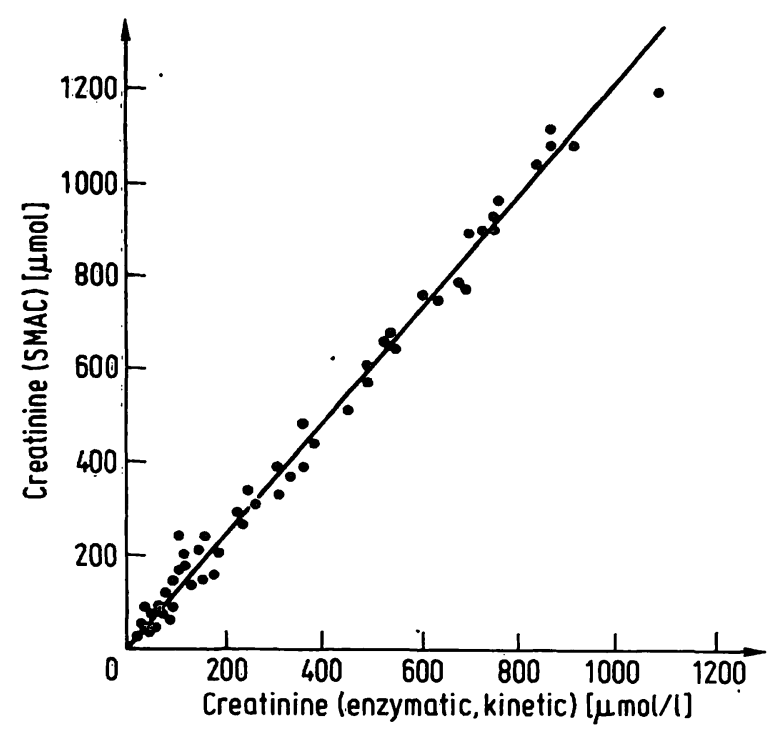

Fig. 4. Comparison of the proposed kinetic enzymatic method with the colorimetric automated continuous flow procedure on SMAC.

$y=8.11 \mu \mathrm{mol} / 1+1.199 x ; r=9962 ; n=87$.

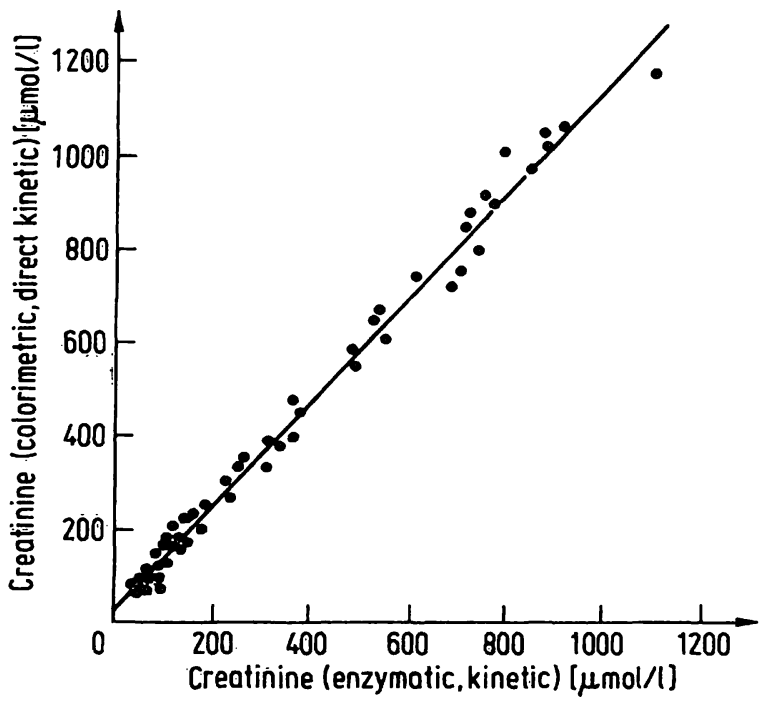

Fig. 5. Comparison of the proposed kinetic enzymatic method with the colorimetric direct kinetic method performed on CentrifiChem. Determination on serum.

$y=29.57 \mu \mathrm{mol} / 1+1.120 x ; \mathrm{r}=0.9967 ; \mathrm{n}=87$.

Tab. 5. Mean values obtained by various methods on 87 serum samples.

\begin{tabular}{llllll}
\hline & $\begin{array}{l}\text { Enzymatic } \\
\text { kinetic method }\end{array}$ & $\begin{array}{l}\text { Enzymatic } \\
\text { end point method }\end{array}$ & $\begin{array}{l}\text { Slot's } \\
\text { (two pHs) method }\end{array}$ & $\begin{array}{l}\text { Direct colorimetric } \\
\text { kinetic method }\end{array}$ & $\begin{array}{l}\text { SMAC } \\
\text { procedure }\end{array}$ \\
\hline$\overline{\mathbf{x}}(\mu \mathrm{mol} / \mathrm{l})$ & 256.2 & 258.4 & 270.9 & 316.5 & 318.0 \\
$\Delta$ & - & -2.2 & -14.7 & -60.3 & -61.8 \\
$\mathbf{t}$ & - & -1.410 & -6.464 & -13.230 & -8.645 \\
$\mathbf{p}$ & - & n.s. & $<0.001$ & $<0.001$ & $<0.001$ \\
\hline
\end{tabular}


The calculation of the regression line gave a very good correlation coefficient with all the three methods (figs. $3,4,5$ ), but the slope was significantly different from 1 and, for the direct kinetic picrate method, the intercept point was significantly different from zero.

A comparison has also been made using the latter method on 41 urine samples. In this case, not only the correlation coefficient was good but the intercept also was at zero (fig. 6).

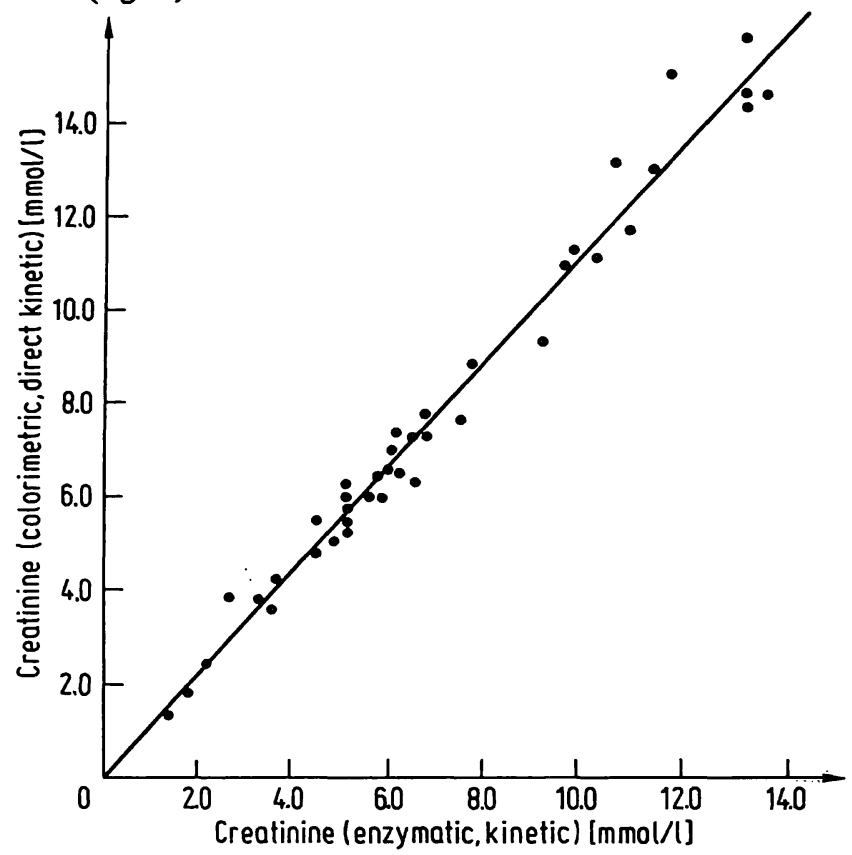

Fig. 6. Comparison of the proposed kinetic enzymatic method with the colorimetric direct kinetic method performed on CentrifiChem. Determination on urine. $\mathrm{y}=0.035 \mu \mathrm{mol} / \mathrm{l}+1.136 \mathrm{x} ; \mathrm{r}=0.9892 ; \mathrm{n}=41$.

Tab. 6. Effect of various substances added to serum on the determination of creatinine with the proposed method.

\begin{tabular}{llcc}
\hline Substances added & & & $\begin{array}{l}\text { Creatinine } \\
\text { found } \\
(\mu \mathrm{mol} / \mathrm{l})^{*}\end{array}$ \\
\hline None & & & 171.5 \\
Citrate & $(\mathrm{mmol} / \mathrm{l})$ & 3.4 & 172.4 \\
EDTA & & 13.6 & 160.9 \\
& $(\mathrm{mmol} / \mathrm{l})$ & 3.2 & 163.5 \\
Heparin & & 16.2 & 17.7 \\
& $(\mathrm{kU} / \mathrm{l})$ & 100 & 174.1 \\
Oxalate & & 500 & 168.0 \\
& $(\mathrm{mmol} / \mathrm{l})$ & 7.5 & 57.5 \\
Ascorbic acid & & 37.3 & 0 \\
& $(\mathrm{mmol} / \mathrm{l})$ & 5.7 & 150.3 \\
Glucose & & 28.4 & 88.4 \\
& & 113.5 & 0 \\
Bilirubin & $(\mathrm{mmol} / \mathrm{l})$ & 5.55 & 172.4 \\
& & 166.5 & 169.7 \\
Haemoglobin, & & 25.6 & 169.7 \\
(from red cell lysates $)$ & $(\mathrm{g} / \mathrm{l})$ & 71.8 & 170.6 \\
& & 102.6 & 194.5 \\
& & 3 & 185.6 \\
& & 5 & 231.6 \\
& & & 265.2 \\
\hline
\end{tabular}

* mean of triplicate assay

\section{Interferences}

The effect of several substances on creatinine determination by the present method was tested; the results are reported on table 6 .

Among anticoagulants, at concentrătions likely to be found in plasma samples, heparin does not interfere and citrate shows only a slight inhibition; in' contrast, EDTA and especially oxalate inhibit very strongly.

Ascorbic acid alşo inhibits the enzymatic reaction but only at rather high concentrations.

Glucose, even at very high conceñtrations, does not interfere. Bilirubin shows a positive interference and an important positive interference has also been found by addition of red cell lysates.

\section{Reference values}

Reference values were established with the propoposed method on 200 healthy adult subjects, 100 males and 100 females.

In agreement with the data reported by Szász for the enzymatic end point procedure (4) the mean values are $71 \pm 16(\mathrm{SD}) \mu \mathrm{mol} / 1(8.1 \pm 1.8 \mathrm{mg} / 1)$ for males and $62 \pm 13(\mathrm{SD}) \mu \mathrm{mol} / 1(7.0 \pm 1.5 \mathrm{mg} / 1)$ for females, within a range of $40-93$ and $35-88 \mu \mathrm{mol} / 1$ respectively.

\section{Discussion and Conclusion}

The kinetic method described, in comparison with the endpoint procedure of the commercial kit, offers the advantages of a simple and rapid semi-automation and of the use of small volumes of serum and reagents:

1) The accessory reactions are practically completely exhausted during the incubation period of $15 \mathrm{~min}$ at $37^{\circ} \mathrm{C}$, prior to the addition of creatinine amido-hydrôlase. This eliminates the need for measuring the blank absorbance.

2) Owing to the reduced volumes of serum and of reagent 1 , the creatinine amido-hydrolase in the final mix ture is about two times as concentrated as in the endpoint method and furthermore the reaction is performed at $37^{\circ} \mathrm{C}$ instead of $25^{\circ} \mathrm{C}$. The reaction rate is therefore enhanced and consequently the sensitivity is high.

In comparison with the kinetic procedure of Moss et al. (3), the concentration of lactate dehydrogenase is higher, and the incubation is longer and performed at higher temperature. These conditions, as mentioned above, reduce the interference of secondary reactions to a very low and constant value, and eliminate therefore the need for the blank for each individual sample, thus making automation possible.

The higher serum concentration in the final mixture and the higher reaction temperature double the $\Delta \mathrm{A}$ value per min per $\mu \mathrm{mol} / 1$ of creatinine in the present procedure. 
When compared with the picrate methods, the enzymatic methods undoubtedly show higher specificity. This is especially appearent in comparison with the direct kinetic method performed in the CentrifiChem. With the two pHs method of Slot the differences are much lower. The differences almost disappear even with the direct kinetic picrate when the determination is performed on urine samples, due to the necessary dilution.

Some anticoagulants inhibit rather strongly the enzymatic reaction; it is therefore advisable to use serum or plasma anticoagulated with heparin, which does not interfere. Icteric or haemolysed samples should not be used, because bilirubin and haemoglobin give a positive interference.

In conclusion, the enzymatic method, contrary to some recent statements (8), when performed under the conditions described, is not only highly specific and accurate, but also sensitive and precise: the speed attainable by automation and the reduction of cost due to the low volumes employed make it suitable also for routine work.

\section{References}

1. Carpenter, C. B. \& Austen, K. F. (1968) The early diagnosis of renal allograft rejection. In Human transplantion (Rapaport, F. T. \& Daus, J. eds.) Grüne and Stratton New York, pp. 151-165.

2. Wahlefeld, A. W., Herz, G. \& Bergmeyer, H. U. (1972) Scand. J. Clin. Lab. Invest. 29, 126, abstract $n^{\circ} 30.1$.

3. Moss, G. A., Bondar, R. J. L. \& Buzzelli, D. M. (1975) Clin. Chem. 21, 1422-1426.

4. Szász, G., Börner, V., Stähler, F. \& Bablok, W. G. (1977) Clin. Chem. 23, 1172, Abstract n 287.
5. Szzász, G., Börner, V. \& Bablok, W. G. (1978) Clin. Chem. 24, 997 , abstract $n^{\circ} 047$.

6. Fabiny, D. L. \& Retingshausen, G. (1971) Clin. Chem. 17, 696-700.

7. Slot, C. (1965) Scand. J. Clin. Lab. Invest. 17, 381-378.

8. Hearne, C. R. \& Fraser, C. G. (1979) Clin. Chem. 25, 1665-1666.

Prof. Giovanni Ceriotti

Laboratorio Centrale di Analisi

Ospedale Civile

I-35100 Padova 
. 